\title{
Processing the Revolution: Exploring the Ways Tunisian Novels Reflect Political Upheavals
}

\section{Charlotte Pardey}

\section{Introduction}

Socio-political transformations can be complicated and messy. Understanding them requires context and an active engagement with the events that goes beyond a descriptive narrative. Literary fiction lends itself to this kind of rationalization or "processing," as I will explain below. Still, an event such as the 2010-11 uprising in Tunisia challenges literary expression; it is almost too overwhelming to be captured in its entirety between the covers of a novel. Yet political events of this scale contain a certain urgency and pervasiveness that pushes writers to narrate them and to put memory into words. This chapter explores how recent Tunisian novels that address the uprising deal with this challenge. Specifically, it analyzes novels that have found acclaim in the Tunisian literary scene. All four works analyzed here were laureates of the Tunisian prize for fiction, the Prix Comar d'Or. The selection of prizewinning novels suggests that the books represent ideas that are present within Tunisian society or at least supported by the jury of the literary award, as the first section of the chapter will explore. Although all four works deal with the uprising, their portrayals of it represent different trends. Some employ autobiographic reflections, with or without comparisons to past revolutions. Others contain family stories, particularly examining the notion of the absent father, and relegate the uprising to the sidelines. These different ways to rework the revolution will be discussed and analyzed below.

C. Pardey $(\bowtie)$

Centrum für Nah- und Mittelost Studien, Philipps-Universität Marburg,

Marburg, Germany

e-mail: pardeyc@staff.uni-marburg.de

(C) The Author(s) 2021

R. Ouaissa et al. (eds.), Re-Configurations, Politik und Gesellschaft des Nahen

Ostens, https://doi.org/10.1007/978-3-658-31160-5_16 
My main argument focuses on the novels' discussion of intimacy and personal experience in politically tumultuous times. Each work seeks a solution to the literary "problem" of how to write about revolutions: How can an author juggle both personal experience of the event and its national relevance? What should such a novel emphasize? A comparison of the works reveals that the revolution is already fading as a central theme of the novels.

\section{Why Analyze Literature?}

Before delving deeper into this investigation, one might ask how analyzing post-revolutionary literature could help contextualize socio-political transformation processes. More specifically, how does a comparative reading of novels help us make sense of the Tunisian uprising of 2010-11 and its aftermath? This chapter hypothesizes that literature is the outcome of a thought process, a rationalization or interpretation that actively engages with the materials or events it portrays by highlighting certain aspects more than others. Literature proposes metaphors, draws parallels, and offers allusions for reworking its subject matter. Moreover, literature is always created in a certain historical and social setting and reflects the worldviews that dominate this setting. Lennard Davis describes this intertwinement as ideological. In his words, "novels do not depict life, they depict life as it is represented by ideology." He goes on to describe fiction as "one of the ways in which the culture teaches itself about itself" (Davis 1987, p. 24 f.). This is another aspect of the "processing" that I am trying to highlight with this article. Since literature is in constant exchange with the societies in which and for which it was written, it not only offers its own processing of events, it also reflects changes in perspective within society itself. Joseph A. Massad suggests in his study Desiring Arabs that the novel functions "as a reading (and writing) of society that is most unintrusive in comparison with other genres of writing and investigation" (Massad 2007, p. 269). As such, an exploration of literary production, particularly novels, from the aftermath of the Tunisian uprising paints a picture of how it has been perceived at different times. By examining novels that were awarded with literary prizes, we can draw conclusions about the ways in which the Tunisian literary establishment wishes the revolutionary events to be read by readers near and far. 


\section{Literary Prizes and Their Influence: The Prix Littéraires Comar d'Or}

Abir Kréfa describes the laureates of the Comar d'Or literary prizes as some of the most visible and respected Tunisian authors (Kréfa 2013, p. 398). Marc Verboord adds more generally that the "winning of literary prizes is an indication of an author's contemporary prestige" (Verboord 2003, p. 266). Accordingly, one can assume that the literary establishment and the officials behind the awards appreciate the four novels discussed in this chapter, which in turn allows certain interpretations regarding the ways in which the Tunisian literary establishment prefers for the revolutionary events to be processed in literature. The Prix Littéraires Comar d'Or are an initiative by Comar Insurance to promote culture in Tunisia and are organized in cooperation with the Ministry of Culture, signifying a connection to the Tunisian state. The prizes have been awarded since 1997 to authors of Tunisian nationality and their works, which can be either published in Tunisia or abroad. The prizes are awarded in different categories and differentiate between Arabic and French, which reflects the prominence in the Tunisian literary landscape of publications in both French and Arabic. While winners of the Comar d'Or in Arabic or French receive 10,000 Tunisian dinars each, the winners of the Prix Spéciaux des jurys win 5000 and winners of the Prix Découverte receive 2500 Tunisian dinars. ${ }^{1}$ In Europe, "the monetary value of literary prizes is quite often secondary," according to Richard Jacquemond, yet this is different in the Arab world, where literary markets are weak and in need of state sponsorship (Jacquemond 2008, p. 47). Publishers or authors can submit novels to be considered for the prizes. A winning author cannot win another prize in the same category for five years. ${ }^{2}$

Authors, journalists, and academics sit on the jury that selects the winning novel. Since the awards' goal is the promotion of literature, being selected might be about literary quality, yet winning the prize is more about economics. This is important, since the Tunisian literary market is dependent on state funding. In addition to the monetary benefits, winning awards also increases a writer's professional status. The publicity for a book enlarges its readership, and meanwhile its author gains professional opportunities. For example, Yamen Manai, the Paris-based winner of the 2017 Comar d'Or, said that winning the prize paved the way to a variety of trips to and readings in Tunisia. ${ }^{3}$

Literary prizes form an archive (Ducas 2013, p. 8), not just of the novels published each year or of the writers and books that had prestige at the time, as was argued at the beginning of this section. The prizes also track which publishers 
have been publishing a successful canon of works. Since the award's inception in 1997, ninety books have been awarded in the different categories, as occasionally two works and their authors were selected per category. While many publishers only received an award in one year, others were more successful. Here are the top five publishing houses, in ascending order of the prizes they received: Arabesques Éditions (four awards), Dār Zaynab li-l-nashr wa-l-tawzī' (five awards), Éditions Elyzad (six awards), Dār Sahar li-1-nashr (seven awards), and Éditions du Sud (thirteen awards). These awards are almost all equally distributed before and after the uprising of 2010-11, indicating that the socio-political transformations did not make one or the other publisher more presentable than under the previous regime. The publishing house Zaynab li-l-nashr wa-l-tawzī' is exempted from this observation, as it was founded in 2013.

Literary prizes can include as well as exclude. As Sylvie Ducas writes: "Comme tout réseau, les prix littéraires sont oxymoriques et paradoxaux: à la fois ouverture et fermeture, lieu de contrôle, de pouvoir ou d'échanges, d'interactions, frontière entre la norme et la marge" (Ducas 2013, p. 216). ${ }^{4}$ In the case of the Comar d'Or, one exclusion is the restriction against applying after winning the previous year. Another exclusionary effect can be that participants need to supply the competition with seven copies of the work to apply; this poses a financial burden for the respective publisher or author. ${ }^{5}$ In terms of the awards' role in facilitating an exchange, this investigation will offer as an example since it brings together four novels that process the Tunisian uprising.

\section{Individual Impressions of Socio-Political Change}

Autobiographical accounts contain an individual perspective and are therefore exempt from the need to give all-inclusive explanations. This perspective was frequently adopted in and after 2011, not only in Tunisia. In Egypt, publications about personal experiences of the Tahrir protests proliferated, and in Syria, personal accounts narrated the beginning of the protests. ${ }^{6}$ Two recent laureates of the Comar d'Or 2017 exemplify fictional versions of this trend from Tunisia: Béchir Garbouj's Passe l'intrus (2016) and Jamila Ben Mustapha's Rupture(s) (2017). The works were written in French and are analyzed below in regard to their representations of the socio-political changes associated with the Tunisian uprising.

In the first novel, a professor reflects on the uprising of 2010-11 against the backdrop of the 1968 Paris protests, which he experienced as a Tunisian exchange student. At the time, he was in love with the mysteriously absent Nadine. Passe l'intrus uses the 1968 Paris protests as a stand-in for the Tunisian uprising. This 
creates a distance from the Tunisian events, which is further increased by focusing on the private instead of the political. While the primary focus of the narrative is on the love affair, which ends during the 1968 protests, the novel itself speaks to and about the Tunisian uprising.

The professor explores what remains from tumultuous times and addresses the vagueness of memory. In the process, he illustrates the difficulties of contextualizing or rationalizing socio-political transformations. His memories are blurred and the different temporal layers of the narrative blend into one another, a strategy that highlights that the Tunisian situation is meant to be understood via the previous protests. Meanwhile, the professor attempts to understand his fascination for the Paris protests, which he became part of almost by coincidence and without expecting the turmoil (Garbouj 2016, p. 13, 155).

In returning to 1968 , Garbouj suggests the possible consequences of 2011 . He alludes to the importance of political changes and protest for the general course of history. The novel shows May 1968 as a political moment of exceptional importance for the twentieth century. The narrative's parallelism suggests that the Tunisian uprising holds comparable importance for the twenty-first century. Both the love affair and the protests have left an impression on the professor's life: decades later, the former lover is still on his mind, although his memories have faded.

The second novel, Ben Mustapha's Rupture(s), similarly addresses in parallel the consequences of socio-political transformation and personal turmoil. The novel, set in Tunisia between 2012 and 2014, follows the character of Inès as she comes to terms with the end of a love affair. In her diary, she processes both her secret relationship with Hassen and the immediate years after the uprising. Their relationship had lasted for over twenty years before it ended in a separation-one meaning of the French word rupture. Hassen, a member of the Tunisian opposition, was forced to emigrate to Lebanon, where Inès visited him regularly. She broke off contact three years before the uprising after being pressured by state security. After the uprising, Hassen returns to Tunisia yet does not approach Inès and instead devotes himself to a political career made possible by the regime change. According to Inès, he has changed and broken ties with former companions. Inès is disappointed, but she works through her heartbreak in her diary and starts to see him as both a political and personal opportunist. By the end of the narrative, she has made peace with Tunis and the situation, although she is aware of the influence of the previous regime and its practices on her own life, as the initial cause of her heartache. Still, she accepts the discrepancies in her life and in her country as she realizes that Hassen is less important for her happiness than her family and friends. 
The novel uses a personal account to study Tunisian post-revolutionary reality and thereby creates a sense of distancing. The political events seem to form the backdrop to Inès's emotional journey, but really the private story is used to comment on political developments. In Inès's words, "la transition d'une situation à l'autre que le pays traverse, n'est pas moins exempte de désordres que celle, aussi chaotique, que je suis en train de vivre jusqu' aujourd'hui" (Ben Mustapha 2017, p. 86 f.). ${ }^{7}$ Accordingly, Inès' initial response to the post-2011 situation is disappointment. She believes that the very same practices of the previous regimethose that negatively influenced her life-are continuing in a different guise. In addition, her fellow Tunisians have failed to keep their word and are striving for their own personal advancement, not that of the community. For Inès, both developments are the result of long economic struggles and repression by those in charge. The novel thus highlights people's vulnerability to the effects of official pressure and socio-political changes on their lives, the other "ruptures" referred to by the title. Ultimately, this is a comment on those socio-political transformations and their effects.

Both novels play with the autobiographical trend that spread immediately after the uprisings in the Arab world (both in blogs and in print). ${ }^{8}$ While they are not strictly autobiographical themselves, the narratives resemble this genre. More obviously in Ben Mustapha's novel, which takes the form of a diary, but also in Gerbouj's novel, a narrator relives and thereby contextualizes the uprising through memories. Both novels avoid giving an all-encompassing overview of the revolutionary moments and still capture their confusion, excitement, and socio-political turmoil. Both books employ distancing techniques that differentiate them from the immediate autobiographical responses that followed the uprisings in the Arab world, which tended to be less sophisticated. The personal sphere is harnessed in portraying uprisings. This is not to say that the uprisings constitute the narrative's primary background. Rather, the personal sphere is being utilized to shed light on the political sphere and its implications for individual lives. The main goal remains the contextualization of the revolutionary moment and its aftermath.

\section{Family Drama Beats Revolutionary References}

One year later in 2018, the Comar d'Or was again awarded to two novels that relate to the contextualization of the Tunisian uprising. In addition, I am jointly considering novels written in Arabic and French, answering Karima Laachir's call for the necessity of such an analysis across language divides (a "reading 
together") to best reflect the literary community of Tunisia's multilingual locale (Laachir 2016, p. 25 f.). In the previous year, the themes of the Arabic novels did not suit such a comparative reading.

In 2018, Ali Bécheur's Les Lendemains d'hier (2017) won the Comar d'Or for the best novel published in French while Inès Abassi's Menzel Bourguiba (2018) received the Prix spécial du jury for a novel in Arabic.

This is Ali Bécheur's second time winning the Comar d'Or; in 2006, he received it for his novel Le Paradis des femmes. Les Lendemains d'hier, his eighth novel, describes a son's effort to narrate his father's success story while rebelling against the father's expectations for him likewise to succeed: "Apprenant année après année que, quoi que je pense ou fasse, quoi que je rêve ou espère, quel que soit ton regard sur moi - fût-il posthume -, je ne serai jamais à ton image, papa" (Bécheur 2017, p. 251). ${ }^{9}$ The father's story is a typical rags-to-riches-narrative. The son of a barber from the Tunis medina, he not only reaches secondary education and becomes a lawyer but also increases his social standing with a successful marriage. In Les Lendemains d'hier, his son tries to come to terms with the legacy left by his late father. In exploring their relationship, he tries to fill the silences it contained by turning his father into the hero of a story that is, for lack of information, semi-fictional: "Tout être humain est impénétrable, on n'en perçoit que la surface, l'intérieur reste invisible" (Bécheur 2017, p. 263). ${ }^{10}$

The narrative is presented in vignettes told from different perspectives (indicated by the personal pronouns $j e, t u, i l)$. Occasionally, this makes it very difficult to differentiate the sections and determine who is speaking or being addressed. Parallel to the narration of the father's story, the novel references Tunisian history from the protectorate era to the 2010-11 uprising. However, the historical events merely serve as the backdrop to the personal storyline. Take, for example, the portrayal of the father's death:

Tu as jeté un regard par la fenêtre, mais ce matin de novembre avait perdu son ciel $[\ldots]$ et tu t'es dit que cette vie-là ne valait plus la peine d'être vécue. [...] Alors tu t'es allongé sur le lit, tu as fermé les yeux. [...] C'était avant la Révolution du jasmin. Parfois je me demande ce que tu en aurais pensé. Rien, peut-être. ${ }^{11}$ (Bécheur 2017, p. 265 f.)

This treatment clearly diverges from the novels discussed above. Bécheur's novel does follow Ben Mustapha's observations regarding the impact of political events on the personal lives of individuals. Yet, here, the socio-political world is merely a point of reference, allowing the reader to date the story and characters and to see them as the children of their times. This indicates a certain distance from the political turmoil, as far as the necessity of commenting on them is con- 
cerned. They form a backdrop that has been normalized; they no longer are the emergency that needs to be the center of attention. They have been absorbed into the lives of the characters and no longer actively determine them. A contextualization has already taken place, and it is therefore no longer necessary to work on that contextualization within the narrative. Other aspects are more important such as the relationship to the father.

The father figure is of metaphorical relevance, as we will see after analyzing the second novel, Inès Abassi's debut novel Menzel Bourguiba. ${ }^{12}$ This book also discusses the relationship with a father, or rather with his absence, and the lack of such a relationship. After her father's death, Jihān comes to terms with the effect of his absence on her upbringing and her adult life. Her father left her mother before she was born and relocated to the United States. Jihān joins her family for the funeral and the reading of his will and is motivated to solve a family mystery: the disappearance of her father's brother thirty years ago. In the meantime, she also learns more about her father. The mystery of the disappearance is partly autobiographical, as the author has mentioned in an interview (Abū 1-Nașr 2018). The novel is narrated from two perspectives: Jihān's accounts are supplemented by chapters written from the point of view of her father's second wife, Sofia.

Parallel to the events of the narrative, the Tunisians rise up against their president. Jihān and Sofia are therefore both stuck in the city of Menzel Bourguiba (Bizerte Governorate) and are forced to stay there longer than planned. Menzel Bourguiba means "Bourguiba's house." This choice of setting could also be a reference to former president Habib Bourguiba, who styled himself as the father of his country and citizens. With his death in 2000, he left behind his "children," who were already under the rule of his successor, Zine El Abidine Ben Ali. Menzel Bourguiba is also the author's hometown, where she feels most inspired to write, as she states in an interview (Abū l-Nașr 2018). Yet it is not only Bourguiba's house that plays a metaphorical role, but also the house of Jihān's father. It is the setting of much of the action of the novel and furthermore shapes its narrative, insofar as the latter is divided into parts that are entitled with reference to the structure of the building (e.g. "al-Ṭābiq al-Arḍī," "ground floor" or "Nāfidha fì-1-țābiq al-thānī," "a window on the second floor").

Moreover, the house exposes the rivalry between Jihān and Sofia: Jihān's father bequethes the Tunisian house to his daughter, while his second wife and their daughter receive his restaurant in Chicago. Sofia is horrified when she hears this at the reading of the will, and exclaims that she will do everything she can to contest it (Abassi 2018, p. 10).

The Tunisian uprising is presented in the novel as an inconvenience that forces the characters to spend time together (Jihān, for example, would like to 
leave earlier, but her aunt does not let her go out of concern for her safety; Abassi 2018 , p. 183). It thus facilitates the remaining action of the novel: the exploration of Jihān's complicated relationship with her father and the investigation into the family secret. Jihān is sad about her father's absence from her life, and she expresses a certain longing for his presence, yet the situation is not shown to leave her incapacitated or utterly helpless. On the contrary, the narrative is resolved by a hopeful dissociation from the complicated family history: Jihān is an adult and able to escape the situation by returning to the life she has built for herself in the capital, rejecting any interest in inheriting her father's house. She continues to live out her own independent future. This can be understood as a suggestion for Tunisia's future, independent from father figures.

Read together, both novels are conspicuous for their discussion of fathers at a time when Tunisia's leadership is in fact facing a crisis of power, a view that can be read in (or at least into) the two books. In its description of the 2018 situation, the International Crisis Group first singles out the ruling party Nidā' Tūnis's internal struggle over control. Second, and more relevant for the context of particularly Menzel Bourguiba, Prime Minister Youssef Chahed lost some of his support from Nidā' Tūnis and al-Nahḍa in summer 2017. He was asked to resign by various political counterparts and was eventually dismissed from his party position. He then decided to found his own party, Tahyā Tūnis. Regardless, his position has been weakened, as has the consensus between Nidā' Tūnis and al-Nahḍa (International Crisis Group 2018; Delmas 2018).

Both works present the uprising of $2010-11$ as a historical backdrop against which characters experience and deal with their personal lives. The implication is that the personal discourse is of greater importance. Abassi comments on the use of history in her literary work in an interview in which she defends historical references and argues that they do not distract from the main narrative. She suggests that she deals with history through her characters' experiences instead of presenting it as a separate discourse (al-Falāh 2016). The necessity of defending this approach, using the historical backdrop, suggests a completely different situation from that of the first two novels discussed. The 2010-11 uprising only plays a role through characters' experience of it, and not as of itself.

That both works were recognized by the Comar d'Or suggests that the novels' normalized approach to political events is resonant, and not exceptional. This is a shift from the earlier works discussed in the previous section. It remains to be seen whether this trend continues in other literary publications. 


\section{Political Upheavals and the Personal Sphere}

A comparison of all four novels reveals a change in the uprising's importance. In the earlier works, the complications of the socio-political transformations were at the center of Rupture(s) and Passe l'intrus, although the authors might have resorted to distancing techniques. The works were about the uprising, insofar as they discussed the events' repercussions and their impact on individual lives. In particular, Jamila Ben Mustapha's Rupture(s) clearly showed a sense of disappointment with post-revolutionary Tunisia and the achievements of the uprising, which no longer seemed as glorious as it had in 2011. Since then, the country has experienced political changes and terrorist attacks, leading to a precarious economic situation, a disappearance of tourism, and stalled improvement in the lives of ordinary Tunisians. Corruption is rife in the country and it is questionable whether Tunisians believe in the power of political leaders to bring about actual change. Chahed's declining support is in fact a result of his initiative to fight corruption (International Crisis Group 2018). This situation can be read between the lines in the more recent novels, Les Lendemains d'hier and Menzel Bourguiba. The revolution as a theme has moved to the background of both books. With a difference of merely one year, one notes a thematic shift from politics' influence on personal lives to a discussion of the personal lives in which political events provide context. We can see a clear return of the private sphere. This is not to say that the personal is not also political, insofar as it can be read as a commentary, but the newer books do not present the uprising itself as the main issue. The political meaning of personal experience is also more allusive: For example, an eager reader can interpret absent father figures as an allusion to the country's leadership issues or its response to its history of autocratic rule by strong male figures.

The personal sphere has entered the texts in regard to questions of memory and remembrance that were already present in the earlier works. These works attempted to make sense of the socio-political transformations through fictional autobiographies and individual memories. In the more recent works, this personal aspect has become the narratives' main concern.

\section{Conclusion}

This chapter explored the ways in which Tunisian novelists have reflected on the uprising of 2010-11 through the lens of four novels awarded prizes by the Prix Comar d'Or. All four novels address the revolutionary events of 2010-11, but in 
different ways. They also illustrate changing trends in responding to the political transformations. The preceding analysis explored the autobiographical trend and, in one case, included an added comparison to another revolutionary moment. I then highlighted a second trend: a return to the private sphere, which relegates political turmoil and its depiction to the sidelines, as context instead of content. However, by presenting family stories and specifically father conflicts, the novels did comment on the internal politics of Tunisia, or could at least be read to do so. This development can be considered a sign of maturity with regards to the reworking of the Tunisian uprising of 2010-11: a move away from the style of political pamphlets to the development of original characters instead of stock characters. Memory is questioned, another indication that the age of testimony is gone. However, the question of how to deal with the past is still at stake. Both Les Lendemains d'hier and Menzel Bourguiba challenge the writing of history; the fleetingness of memory was already alluded to in Rupture(s) and Passe l'intrus.

Given that the two more recent novels were chosen as the winners of the Comar d'Or in 2018, one can assume that the Tunisian literary establishment currently favors this approach to the revolutionary events in literature. None of the recent protagonists were described as actively participating in the protests. Instead, they were portrayed as uninvolved observers. This suggests a much calmer perspective than a portrayal of a protest that simply develops, as one can read in Kamāl al-Riyākh̄̄'s al-Gürillā (2011), for example. The sense of calm presented here could be interpreted as a sign of an official effort to de-escalate, to return to docile civic life. Yet the move away from partisan writing also allows for a greater depth of language and style, as the narratives become more complicated and technically more sophisticated literary works. It remains to be seen what the next stage of the literary processing of the revolution might be: an ultimate focus on the personal sphere without any references to the uprising?

\section{Endnotes}

1. Official website of the Comar d'Or, https://www.comar-d-or.tn/Fra/image. php?id=113 (accessed 16 August 2019).

2. Ibid.

3. Yamen Manai read from his awarded novel L'Amas ardent on 2 November 2017, at the Faculté des Sciences Humaines et Sociales de Tunis. I had the opportunity to attend the reading and the ensuing discussion at which Manai described invitations and events in Tunisia following the Comar d'Or award.

4. "Like any network, literary prices are oxymorical and paradoxical: both openings and closings; places of control, of power or of exchanges, of inter- 
actions; the border between the norm and the marginal." (All translations from French are by the author).

5. Moncef Chebbi, the director of Arabesques Éditions suggested this difficulty to me in a personal conversation during the Tunis book fair in 2016.

6. For example: Mona Prince's Ismī Thawra, 2012; published in English under the title Revolution is my Name. An Egyptian Woman's Diary from Eighteen Days in Tahrir in 2014 or Samar Yazbek's 2012 Taqātu 'nīrān: min yawmiyyāt al-intifäda al-sūriyya that also appeared in English translation in 2014 as A Woman in the Crossfire: Diaries of the Syrian Revolution.

7. "The transition from one situation to another that the country experiences is no less disorderly than the equally chaotic one that I am currently living."

8. For blogs see: Teresa Pepe's Blogging from Egypt. Digital Literature, 20052016, Edinburgh University Press (2019), for print see note v.

9. "I learned year after year, no matter what I thought or did, what I hoped or dreamed, or what your view of me was - may it even be a posthumous one I would never be like you, papa."

10. "Every human being is impenetrable, one only ever perceives the surface, the inside remains invisible."

11. "You looked out of the window, but this November morning had lost its sky [...] and you said to yourself that this life was no longer worth to be lived. [...] So you stretched out on the bed and closed your eyes. [...] This was before the Jasmin Revolution. Sometimes I wonder what you would have thought about it. Nothing, perhaps."

12. A journalist by profession, Abassi published a collection of short stories inspired by a six-months residence in Seoul, South Korea, as well as poetry collections that found acclaim. Her collection Arshïf al-'A 'mā (The Archive of the Blind) won Tunisia's CREDIF prize in 2007.

\section{References}

'Abbāsī, 'Īnās al- [Inès Abassi]. 2018. Manzil Būrqība [Menzel Bourguiba]. Beirut: Dār al-Sāqī \& AFAC.

Abū l-Nașr, Munā. 2018. 'Īnās al- 'Abbāsī li-l- 'ayn al-'ikhbāriyya': Al-kitāb al-tūnsī yu 'ān̄̄

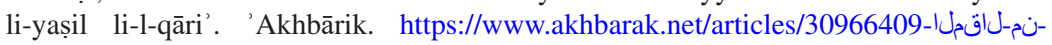

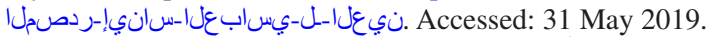

Bécheur, Ali. 2017. Les lendemains d'hier. Tunis: Éditions Elyzad.

Ben Mustapha, Jamila. 2017. Rupture(s). Tunis: Éditions Déméter.

Davis, Lennard J. 1987. Resisting novels. Ideology and fiction. New York: Methuen. 
Delmas, Benoît. 2018. Tunisie: le chef du gouvernement congédié par son parti. Le Point. https://www.lepoint.fr/afrique/tunisie-le-chef-du-gouvernement-congedie-par-sonparti-15-09-2018-2251506_3826.php. Accessed: 29 May 2019.

Ducas, Sylvie. 2013. La Littérature à quel(s) prix? Histoire des prix littéraires. Paris: La Découverte.

Falāḥ, Ḩulūd al-. 2016. 'Inās al-'Abbāsī: ' Ufaḍḍil al-riwāya 'alā kutub al-tārīkh.' Al-'arab.

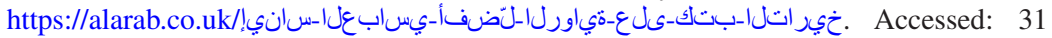
May 2019.

Garbouj, B.échir. 2016. Passe l’intrus. Tunis: Éditions Déméter.

International Crisis Group. 2018. Restoring Public Confidence in Tunisia's Political System. https://www.crisisgroup.org/middle-east-north-africa/north-africa/tunisia/62-tunisie-depasser-les-querelles-pour-restaurer-la-confiance. Accessed: 16 August 2019.

Jacquemond, Richard. 2008. Conscience of the Nation. Writers, State, and Society in Modern Egypt. Trans. David Tresilian. Cairo: The American University in Cairo Press.

Kréfa, A. 2013. La Quête de l'autonomie littéraire en context autoritaire: Le cas des écrivains tunisiens. Sociologie 4 (4): 395-411.

Laachir, K. 2016. The aesthetics and politics of 'reading together' Moroccan novels in Arabic and French. The Journal of North African Studies 21 (1): 22-36.

Massad, Joseph A. 2007. Desiring Arabs. Chicago: University of Chicago Press.

Riyākhī, Kamāl al-. 2011. al-Gūrillā [The Gorilla]. Beirut: Dār al-Sāqī.

Verboord, M. 2003. Classification of authors by literary prestige. Poetics 31: 259-281.

Charlotte Pardey is a research fellow at the Center for Near and Middle Eastern Studies at Philipps-Universität Marburg (Germany). Her research background is in Arabic and Comparative Literature. Her PhD thesis (2018, forthcoming) dealt with the figurations of human bodies in Tunisian novels originating between the country's independence and the protests of 2010/2011. Her research interests lie in both arabophone and francophone literary works from North Africa.

Open Access This chapter is licensed under the terms of the Creative Commons Attribution 4.0 International License (http://creativecommons.org/licenses/by/4.0/), which permits use, sharing, adaptation, distribution and reproduction in any medium or format, as long as you give appropriate credit to the original author(s) and the source, provide a link to the Creative Commons license and indicate if changes were made.

The images or other third party material in this chapter are included in the chapter's Creative Commons license, unless indicated otherwise in a credit line to the material. If material is not included in the chapter's Creative Commons license and your intended use is not permitted by statutory regulation or exceeds the permitted use, you will need to obtain permission directly from the copyright holder.

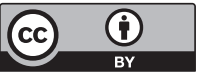

